\title{
Extrafloral nectar increases seed removal by ants in Turnera ulmifolia
}

\author{
Emily M. Dutton, Joel S. Shore, Megan E. Frederickson
}

Version Post-print/accepted manuscript

Citation Dutton, E. M., Shore, J. S., \& Frederickson, M. E. (2016). Extrafloral nectar

(published increases seed removal by ants in Turnera ulmifolia. Biotropica, 48(4), 429-

version) 432.

DOI https://doi.org/10.1111/btp.12342

Publisher's This is the peer reviewed version of the following article:

Statement Extrafloral nectar increases seed removal by ants in Turnera ulmifolia, which has been published in final form at https://doi.org/10.1111/btp.12342 This article may be used for noncommercial purposes in accordance with Wiley Terms and Conditions for Use of Self-Archived Versions.

How to cite TSpace items

\begin{abstract}
Always cite the published version, so the author(s) will receive recognition through services that track citation counts, e.g. Scopus. If you need to cite the page number of the author manuscript from TSpace because you cannot access the published version, then cite the TSpace version in addition to the published version using the permanent URI (handle) found on the record page.
\end{abstract}

This article was made openly accessible by $U$ of $T$ Faculty. Please tell us how this access benefits you. Your story matters. 
LRH: Dutton, Shore, and Frederickson

RRH: Extrafloral Nectar Increases Ant Seed Removal

\section{Extrafloral Nectar Increases Seed Removal by Ants in Turnera ulmifolia}

Emily M. Dutton ${ }^{1,3}$, Joel S. Shore ${ }^{2}$ and Megan E. Frederickson ${ }^{1}$

${ }^{1}$ Department of Ecology and Evolutionary Biology

University of Toronto

25 Harbord Street

Toronto, Ontario

M5S 3G5

${ }^{2}$ Department of Biology

York University

115 Ottawa Road

Toronto, Ontario

M3J 1P3

${ }^{3}$ Corresponding author; email: emily.m.dutton@gmail.com

Received ; revision accepted 


\section{ABSTRACT}

2 To investigate whether extrafloral nectar (EFN) increases seed dispersal in Turnera ulmifolia we 3 measured seed removal on plants with and without EFN. Plants producing EFN had more seeds

4 removed than control plants, suggesting that EFN does play a role in seed dispersal. This is a

5 novel function of EFN.

6

7 Keywords: ant defense; extrafloral nectar; Florida; seed dispersal; mutualism; myrmecochory

${ }^{3}$ Corresponding author; email: emily.m.dutton@gmail.com

Received ; revision accepted 
1 Extrafloral nectaries, sugar-secreting glands on plant parts other than flowers (Elias et al. 1975),

2 occur on more than 4000 plant species (Weber and Keeler 2013). They are almost always

3 involved in ant defense (Weber \& Agrawal 2014), and occasionally attract pollinators (Knox et

4 al. 1985). Cuautle et al. (2005) found that Turnera ulmifolia attracts ants for both defense and

5 seed dispersal, and many ant species collecting EFN from T. ulmifolia also collect elaiosome-

6 bearing seeds. They hypothesized that EFN increases seed dispersal on T. ulmifolia. Here, we

7 test this hypothesis by manipulating EFN production and measuring seed removal, providing the

8 first experimental evidence that EFN increases seed dispersal. We also investigate phenological

9 changes in EFN production as a possible mechanism by which plants alter ant visitation.

10 We conducted our field experiment from 21 to 25 September 2014 at the edge of a

11 tropical hardwood hammock located in John Pennekamp Coral Reef State Park (2507’32” N,

$1280^{\circ} 24^{\prime} 22^{\prime}$ W, elevation $\sim 1 \mathrm{~m}$ asl), Key Largo, Florida, U.S.A. The climate is warm and humid,

13 with ten-year average September temperature and precipitation of $28^{\circ} \mathrm{C}$ and $200 \mathrm{~mm}$ respectively

14 (NOAA National Climatic Data Centre, Florida Keys Time Series, 2014). Turnera ulmifolia

15 plants were located in a large patch ( $\sim 60$ plants) dominated by poisonwood (Metopium

16 toxiferum) and sea grape (Coccoloba uvifera).

17 Turnera ulmifolia L. is a weedy, perennial shrub native throughout South America and

18 the West Indies, and naturalized in Florida (Barrett 1978). Each leaf has a pair of extrafloral

19 nectaries on the petiole (Elias et al. 1975, Gonzalez 1996). Flowers are ephemeral, opening once

20 for three to five hours, and located on the distal portion of the petiole, directly above extrafloral

21 nectaries (Elias et al. 1975). In most regions, including Florida, plants flower and set fruit year 
1 round with a peak in the rainy season (Cuautle et al. 2005). Thus, many individuals display all

2 phenological stages simultaneously throughout the year. Fruits are axial, small, round, usually

3 green, dehiscent capsules that take about $21 \mathrm{~d}$ to develop (Cuautle et al. 2005, Salazar-Rojas et

4 al. 2012). Seeds are about $3 \mathrm{~mm}$ long and bear large elaiosomes (Barrett 1978, Cuautle et al.

$52005)$.

To determine if EFN plays a role in seed dispersal in T. ulmifolia, we manipulated EFN

7 secretion and measured the effect on ant abundance and seed removal. The week before the

8 experiment, seeds were collected daily from 28 T. ulmifolia plants and stored in an air-tight

9 container. We then randomly assigned each plant to one of two treatments: an EFN exclusion

10 treatment in which we applied clear nail polish on all extrafloral nectaries on the plant to prevent

11 nectar secretion, and a control treatment in which we applied clear nail polish near, but not on,

12 extrafloral nectaries. The nail polish did not appear to damage plant tissues (E. Dutton, pers.

13 obs.) and similar methods have been used previously (Rudgers \& Gardener 2004); furthermore,

14 any effects of nail polish were consistent across treatments. Starting the day after we imposed the

15 treatments, each morning between $0900 \mathrm{~h}$ and $1100 \mathrm{~h}$ for three days, we took a snapshot count of

16 all ants on each plant and identified them to species. Immediately following, we taped a

17 microcentrifuge tube cap to an upper leaf on each plant (where fruits are normally found) and

18 added 10 T. ulmifolia seeds (the number of seeds in a typical fruit in this population). We put

19 seeds in these "depots" instead of using dehiscing fruits to standardize the number, quality, and

20 presentation of the seeds. After an hour, we counted the number of seeds remaining. We

21 measured ant presence and seed removal in the morning because this is when seeds were 
1 normally most available. We analyzed the effect of treatment on the three-day average of ant

2 abundance and number of seeds removed using a generalized linear model (GLM) with quasi-

3 poisson errors in R v. 3.0.2 (R Core Team 2013).

4 One caveat of our experimental design is that we measured removal, not dispersal.

5 However, seed removal is often used as a proxy for seed dispersal, and is thought to closely

6 relate to seed dispersal (Carney et al. 2003, Zelikova et al. 2008, Türke et al. 2012).

7 Furthermore, ant composition was similar between treatments, suggesting any difference

8 between removal and dispersal was consistent between treatments, although we did not formally 9 test this.

10 EFN secretion increased ant abundance and seed removal. Control plants with active 11 extrafloral nectaries had $7.8 \pm 1.7$ (mean $\pm 1 \mathrm{SE}$ ) ants per plant, whereas EFN-excluded plants

12 had $3.0 \pm 0.4$ ants per plant, a significant decrease in ant abundance $\left(F_{1,26}=10.14, P<0.01\right)$.

13 Similarly, control plants had 5.0 \pm 0.8 seeds removed, whereas EFN-excluded plants had $2.6 \pm$

140.5 seeds removed, a decrease of almost 50 percent $\left(F_{1,26}=6.21, P=0.019\right)$.

15 Our results suggest that EFN increases seed removal (and likely seed dispersal) in $T$.

16 ulmifolia. Given that only $\sim 1 \%$ of seeds successfully germinate (Salazar-Rojas et al. 2012), such

17 an increase probably affects reproductive success. Thus, our study provides the first experimental

18 evidence of a novel function of EFN and supports the hypothesis suggested by Cuautle et al.

19 (2005). The continuous presence of ants at extrafloral nectaries may decrease the time it takes

20 ants to discover and remove seeds, especially given their close physical proximity (Elias et al.

21 1975), thereby reducing the risk of falling to the ground where predation by red land crabs 
1 (Gecarcinus lateralis) is high (Salazar-Rojas et al. 2012). Additionally, seeds may be more likely

2 to be removed by omnivorous, scavenging ants that typically act as high quality dispersers

3 (Cuautle et al. 2005, Prior et al. 2015). Interestingly, many myrmecochorous plants have

4 prostrate fruits, but T. ulmifolia seeds stay attached to the valves of fruits during dehiscence,

5 meaning most seeds $(\sim 92 \%)$ are removed from on (rather than beneath) the plant, where they

6 remain close to extrafloral nectaries (Cuautle et al. 2005, Salazar-Rojas et al. 2012).

7 The most common ants on T. ulmifolia were Wasmannia auropunctata (75\% of plants),

8 Paratrechina longicornis (43\% of plants), Camponotus floridanus (18\% of plants), Tapinoma

9 melanocephalum (4\% of plants), and Brachymyrmex obscurior ( $4 \%$ of plants), all of which were

10 observed collecting EFN. There were no clear differences in ant composition between

11 treatments. Wasmannia auropunctata is often considered a poor disperser because it can remove

12 elaiosomes in situ (Rico-Gray \& Oliveira 2007); however, we repeatedly observed $W$.

13 auropunctata removing seeds with elaiosomes attached and carrying them to the forest floor,

14 suggesting effective dispersal. Furthermore, seeds that remained at the end of the experiment

15 always had intact elaiosomes, suggesting that $W$. auropunctata does not "rob" T. ulmifolia

16 elaiosomes. Paratrechina longicornis was also observed removing entire seeds with elaiosomes,

17 and can effectively disperse seeds of many myrmecochorous plants (Rico-Gray \& Oliveira

18 2007). Little is known about the seed-dispersing efficacy of the other three ant species. Only ant

19 species that also visited extrafloral nectaries were observed collecting seeds.

Knowing that EFN increases seed removal, a possible mechanism by which plants may

21 enhance seed dispersal is by increasing EFN production at fruit dehiscence. To explore this, we 
1 studied a population of T. ulmifolia plants collected in Ewarton, Jamaica in 1994 and propagated

2 vegetatively in glasshouses $\left(23-32^{\circ} \mathrm{C}\right)$ at York University, Toronto, Canada (43 $46^{\prime 2} 29^{\prime \prime} \mathrm{N}$,

$3 \quad 79^{\circ} 30^{\prime} 18^{\prime} \mathrm{W}$ ). Ants frequently visit extrafloral nectaries on T. ulmifolia in Jamaica (Barrett

4 1978), much as they do in Florida, but we do not know whether these populations differ in EFN

5 production, nor how EFN production is affected by glasshouse conditions. On glasshouse plants

6 in 2015, we simultaneously measured EFN production at extrafloral nectaries on bare leaves and

7 on leaves subtending floral buds, open flowers, wilted flowers (one day after flowering), and

8 fruits before (1 day to maturation), during, and after dehiscence. Fruits were produced by hand-

9 pollinating flowers the required number of days before taking measurements. Thus, all 10 plants

10 had pairs of extrafloral nectaries at every stage, which were measured simultaneously. We

11 removed EFN $24 \mathrm{~h}$ prior to taking measurements to ensure the same amount of time for nectar

12 accumulation across stages and to mimic field conditions where ants regularly remove nectar.

13 We collected nectar from both extrafloral nectaries on one leaf at each phenological stage on

14 each plant in $5 \mu \mathrm{L}$ microcapillary tubes (Drummond Scientific Company, Broomall, USA) and

15 determined volume by measuring the height of nectar with microcalipers. We diluted samples

16 with known volumes of $0.5-3.0 \mu \mathrm{L}$ of distilled water and measured concentration $\left({ }^{\circ}\right.$ Brix) with a

17 low-volume hand-held refractometer (Bellingham and Stanley, Kent, UK). We estimated sugar

18 mass per $\mathrm{mL}$ following Búrquez and Corbet (1991) and multiplied this by nectar volume to

19 obtain sugar mass. We analyzed the data in R v. 3.0.2 using a linear mixed model with sugar

20 mass (square-root transformed) as the response variable, stage as a fixed effect, and plant ID 
1 treated as a random blocking factor, followed by a Tukey-adjusted least-squares mean test to

2 compare phenological stages.

3 EFN production peaked when the flower bloomed and just before the fruit dehisced $\left(F_{6,54}\right.$

$4=21.2, P<<0.0001$; Fig. 1). The peak at flowering is common to most species with extrafloral

5 nectaries (Marazzi et al. 2013). The peak immediately before dehiscence may attract seed-

6 dispersing ants. Although the peak in nectar production occurred the day before fruit dehiscence,

7 it can take some ant species a long time to update their foraging locations in response to shifting

8 food availability (Beckers et al. 1990, Grüter et al. 2012), and of course there is food available

9 close by in the form of elaiosomes once fruits dehisce. Because different phenological stages are

10 present on the same plant simultaneously, the peak in EFN production at fruit dehiscence

11 probably shifts the distribution of EFN (and ants) within the plant, more than it changes a plant's

12 total EFN production. Alternatively, the peak near dehiscence may attract ants to defend against

13 seed predators.

14 Our field and glasshouse results suggest T. ulmifolia may have experienced stronger

15 selection for EFN production during fruit development than other extrafloral nectary-bearing

16 plants because of the additional selective advantage of attracting seed-dispersing ants. Of course,

17 this requires further investigation as we worked on non-native populations and we know little

18 about the evolutionary history of this ant-plant interaction. Our previous work in the same

19 population demonstrated that ants collecting EFN decrease florivory (Dutton et al., in press),

20 perhaps explaining the peak in production at flowering. This also suggests the intriguing

21 possibility that in T. ulmifolia EFN may be an "ecologically pleiotropic" trait (sensu Strauss \& 
1 Irwin 2004). Ecological pleiotropy has previously been documented between antagonists and

2 mutualists; however is rarely considered between two mutualists (Brody 1992, Galen \& Cuba

3 2001, Strauss \& Irwin 2004). Future studies could determine if there are additive or synergistic

4 effects of defense and dispersal that could increase the strength of positive selection (compared

5 to the effect of only one mutualism) on EFN (Afkhami et al. 2014).

6 In this study, we demonstrated for the first time that EFN can play a role in seed

7 dispersal. While beneficial for seed dispersal, the effects on plant defense are unknown. In many

8 taxa, the nutrient composition of elaiosomes has converged with that of insects. Consumption of

9 elaiosomes could decrease the appetite of ants for insect herbivores (Hughes et al. 1994, Rico-

10 Gray \& Oliveira 2007), negatively impacting defense. However, this would have to be tested

11 explicitly. Ants that visit extrafloral nectaries can also harass or deter pollinators, with mixed

12 effects on seed set (Ness 2006, Gonzálvez et al. 2013), suggesting that attracting ants with EFN

13 to increase seed dispersal could come at the cost of seed production; however this would also

14 require further investigation. It is unknown how many myrmecochorous plants also produce

15 EFN, although similar relationships are likely throughout the genus Turnera, and possibly in

16 Acacia where ants have been observed dispersing seeds and collecting EFN (Rudgers and

17 Gardener 2004).

18

19 ACKNOWLEDGEMENTS 
1 We thank Joshua King for identifying ants; the Florida State Park staff for field assistance;

2 Ceilidh Dutton for help with the figure; and anonymous reviewers for their comments. An

3 Ontario Graduate Scholarship to EMD, NSERC Discovery Grants to JSS and MEF, and an Early

4 Researcher Award from the Ontario Ministry of Economic Development and Innovation to MEF

5 funded this research. A scientific (non-commercial) research/collecting permit (no. 09041415)

6 was issued by the Florida Department of Environmental Protection, Division of Recreation and

7 Parks, Florida Parks Service. 


\section{LITERATURE CITED}

2

3 AfKhAmi, M. J. Rudgers, AND J. Stachowicz, Multiple mutualistic effects: conflict and

$4 \quad$ synergy in multispecies mutualisms. Ecology 95: 833-844.

5

6
BARRETT, S. C. H., 1978. Heterostyly in a tropical weed: the reproductive biology of Turnera ulmifolia complex (Turneraceae) Can. J. Bot 56: 1713-1725.

Beckers, R., J. L. Deneubourg, S. Goss, And J. M. Pasteels, 1990. Collective decision making through food recruitment. Insectes Soc. 37: 258-267.

Brody, A. K., 1992. Oviposition choices by a pre-dispersal seed predator (Hylemya sp.) - I. Correspondence with hummingbird pollinators, and the role of plant size, density and floral morphology. Oecol. 91: 56-62.

BúRQueZ, A. AND S. CORBET, 1991. Do flowers reabsorb nectar? Funct. Ecol. 5: 369-379.

Carney, S. E., M. B. Byerley, D. A. Holway, 2003. Invasive Argentine ants (Linepithema humile) do not replace native ants as seed dispersers of Dendromecon rigida (Papaveraceae) in California, USA. Oecol. 135: 576-582.

Cuautle, M., V. Rico-Gray, And C. Diaz-Castelazo, 2005. Effects of ant behaviour and presence of extrafloral nectaries on seed dispersal of the Neotropical myrmecochore Turnera ulmifolia L. (Turneraceae). Biol. J. Linn. Soc. 86: 67-77.

Dutton, E.M., E.Y. Luo, A.R. Cembrowski, J.S. Shore, And M.E. Frederickson, 2016. Three's a crowd: Trade-offs between attracting pollinators and ant bodyguards with nectar rewards in Turnera. Am. Nat. In press. 
1 Elias, T. S., W. R. Rozich AND L. NEWCOMBE, 1975. The foliar and floral nectaries of Turnera ulmifolia L. Am. J. Bot. 62: 570-576.

3 Galen, C., AND J. CuBA, 2001. Down the tube: pollinators, predators, and the evolution of

4 flower shape in the alpine skypilot, Polemonium viscosum. Evolution. 55: 1963-1971.

5 GonZalez, A. M., 1996. Nectarios extraflorales en Turnera, series Canaligerae y Leiocarpae. Bonplandia 9: 129-143.

7 GonzÁlvez, F.G., L. SANTAmaríA, R. T. Corlett, And M. A. RodríGuez-Gironés, 2013. Flowers attract weaver ants that deter less effective pollinators. J Ecol. 101: 78-85.

9 Grüter, C., R. Schürch, T. J. Czaczkes, K. TAylor, T. Durance, S. M. Jones, F. L. W. RATNIEKS, 2012. Negative feedback enables fast and flexible collective decision-making $11 \quad$ in ants. PLOS One 7: e44501.

12 Hughes, L., M. Westoby, And E. Jurado, 1994. Convergence of elaiosomes and insect prey: evidence from ant foraging behaviour and fatty acid composition Funct. Ecol. 8: 358-365.

14 Knox, R.B., J. Kenrick, P. Bernhardt, R. MArginson, G. Beresford, I. BAKer, And H.G. BAKER. 1985. Extrafloral nectaries as adaptations for bird pollination in Acacia terminalis. Am. J. Bot. 72: 1185-1196.

17 Marazzi, B., E. Conti, M. J. SAnderson, M. M. McMahon, And J. L. Bronstein, 2013.

18 Diversity and evolution of a trait mediating ant-plant interactions: insights from extrafloral 19 nectaries in Senna (Leguminosae). Ann. Bot. 111: 1263-1275.

20 NESS, J. H., 2006. A mutualism's indirect costs: the most aggressive ant bodyguards also deter pollinators. Oikos 113: 504-514. 
1 Prior, K., J. Robinson, S. MeAdley-Dumphy, AND M. E. Frederickson, 2015. Mutualism

2 between co-introduced species facilitates invasion and alters plant community structure.

3 Proceedings Biol. Sci. / R. Soc. 282: 20142846.

4 R CORE TEAM, 2013. A language and environment for statistical computing. Available at:

$5 \quad$ http://www.r-project.org/.

6 Rico-Gray, V., AND P. S. Oliveira, 2007. The Ecology and Evolution of Ant-Plant Interactions,

7 Chicago: The University of Chicago Press.

8 Rudgers, J. A., AND M. C. GARDENER, 2004. Extrafloral nectar as a resource mediating

$9 \quad$ multispecies interactions. Ecology 85: 1495-1502.

10 Salazar-Rojas, B., V. Rico-Gray, and A. CANTO, AND M. Cuautle, 2012. Seed fate in the

11 myrmecochorous Neotropical plant Turnera ulmifolia L., from plant to germination. Acta

12 Oecol. 40: 1-10.

13 StRAUSS, S. AND R. IRWIN, 2004. Ecological and evolutionary consequences of multispecies

14 plant-animal interactions. Annu. Rev. Ecol. Evol. Syst. 35: 435-466.

15 TÜrke, M. K., K. Andreas, M. M. Gossner, E. Kowalski, M. Lange, S. Boch, S. A. Socher,

16 J. Müller, D. Prati, M. Fischer, R. MeyhöFer, And W. W. Weisser, 2012. Are

17 gastropods, rather than ants, important dispersers of seeds of myrmecochorous forest

18 herbs? Am. Nat. 179: 124-131.

19 Weber, M. G., AND A. A. Agrawal, 2014. Defense mutualisms enhance plant diversification.

20 Proc. Natl. Acad. Sci. 111: 16442-16447.

21 WeBER, M.G., AND K.H. KEELER, 2013. The phylogenetic distribution of extrafloral nectaries in 
1 plants. Ann. Bot. 111: 1251-1261.

2 ZELIKOVA, T. J., R. R. DunN, N. J. SANDERS, 2008. Variation in seed dispersal along and

3 elevational gradient in Great Smoky Mountains National Park. Acta Oecol. 34: 155-162. 


\section{$1 \quad$ Figure Legends}

2 FIGURE 1. Mass of extrafloral nectar sugar (mean \pm 1SE) produced by one nectary pair over 24

3 hours at various phenological stages (depicted in line drawings). Arrows indicate the locations of

4 extrafloral nectaries. Letters indicate statistically different stages based on a Tukey-adjusted

5 least-squares means test $(\mathrm{P}<0.05)$. 
Figure 1

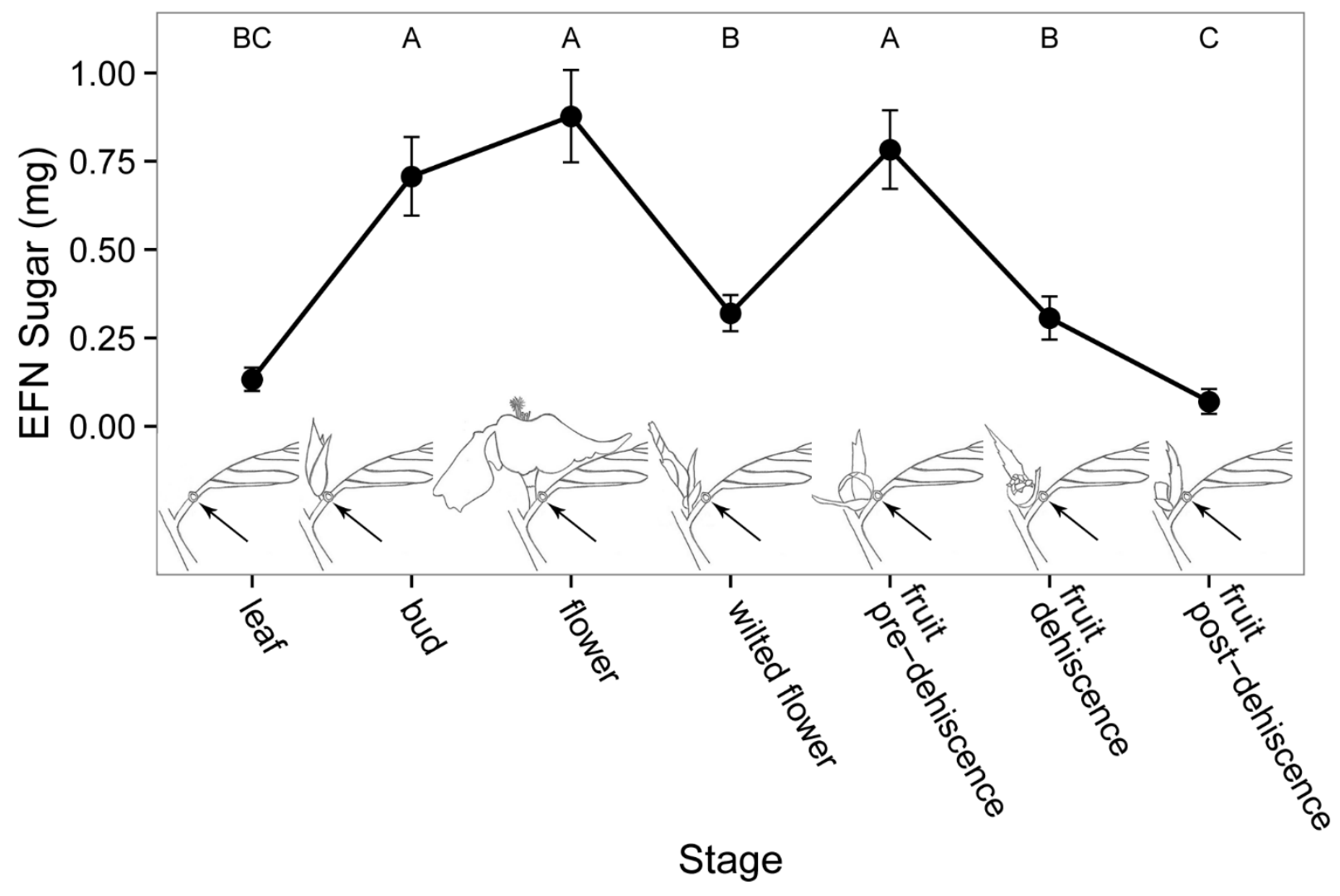

